"This is the peer reviewed version of the following article: Denham, J. (2017), A New Progressive Patriotism. The Political Quarterly, 88: 97-105. doi:10.1111/1467-923X.12326, which has been published in final form at http://dx.doi.org/10.1111/1467-923X.12326. This article may be used for non-commercial purposes in accordance with Wiley Terms and Conditions for Self-Archiving." (C) 2017 Wiley-Blackwell

\title{
A new Progressive Patriotism
}

\section{John Denham}

\section{Introduction}

The 'progressive dilemma' has changed. For David Marquand it was primarily about how the centre left appealed 'beyond Labourism'. Today, social democracy is losing its key social base as economic change undermines mass working class culture and organisation. For all the realities of dramatic economic and social change, the need to hold capital to account and to bend markets to the common good is as powerful as ever. Yet it is becoming ever harder to create an electoral or political majority for such an idea in societies that are fractured and divided. The fundamental bond between voters and parties depends on political identity relationships; old ones are fading, new ones need to be created. Migration in particular has had a corrosive effect on a significant part of the electorate's traditional identification with Labour. This essay argues that the most dynamic politics in advanced capitalist societies are those of nation, people and place. The strategic challenge for the left is to create a new progressive patriotism that can embed radical ideas in a common sense of national purpose.

\section{Capitalism is still the challenge - the historic mission of social democracy}

Social democracy was born in response to the majority's interest in challenging unrestrained capitalism. Left to themselves, markets consistently create and re-create unaccountable concentrations of power and wealth, pitting the interests of a small group of powerful and wealthy individuals, corporations and financial institutions against the interests of the majority, within nations and across the world. The consequence is inequality nationally and globally, insecurity, instability and uncertainty.

These risks have been underlined by the sluggish and uneven response to the banking crisis itself born from the illusion that markets could solve their own problems. The threat of a new crash is ever-present. Some countries have enjoyed rapid growth, as have some cities including London. But the patterns of growth have been uneven, the impact of new technologies skewed, throwing up a slew of problems. The EU, once seen by the centre left as a vehicle for both capitalist growth and social justice, is stalled without delivering the dynamic, innovative, world leading region it promised. Even in wealthy countries millions are excluded from the benefits of growth. Markets like UK housing are failing the majority of young people. Inequality is rising sharply. Global inequalities of wealth and income are driving mass migration on a scale that is unsustainable, erodes communities, and is politically toxic.

On the other hand, despite these concerns global markets cannot fail to impress with their dynamism and entrepreneurialism. In 20 years, globalisation has lifted more billions out of poverty in developing countries than 70 years of aid. It is hard to imagine a world where the centre left turns its back on the innovation and creativity that is fostered by properly functioning markets. As David Marquand described, the left has always oscillated between an ill-defined anti-market socialism, and attempts to deliver social justice within a market system. But the challenge of "The Progressive Dilemma' has not turned out the way he expected.

20 years ago progressive politicians were confident. New Labour was about to win the 1997 UK election; social democrats who were winning in Europe shared a similar world view to the Clinton Democrats. Notwithstanding the tensions between an 'Anglo-Saxon' view of markets and the more 
"This is the peer reviewed version of the following article: Denham, J. (2017), A New Progressive Patriotism. The Political Quarterly, 88: 97-105. doi:10.1111/1467-923X.12326, which has been published in final form at http://dx.doi.org/10.1111/1467-923X.12326. This article may be used for non-commercial purposes in accordance with Wiley Terms and Conditions for Self-Archiving." (c) 2017 Wiley-Blackwell

state orientated traditions of continental Europe the left was winning the arguments. But, not for the first time, the left was making the mistake of believing that capitalism had changed in ways that worked in the interests of progressive politics.

In the 1950s, revisionists like Crosland thought that Keynesian economic management, coupled to the development of technocratically managed companies, could ensure growth and full employment. The challenge appeared to be to open opportunities to all for fulfilling lives by education, meritocracy and the progressive redistribution of the proceeds of growth. The stagnation of the 1970s showed the limits of this approach in the UK while successive oil crises and persistent high inflation ushered in a period of global slowdown and uncertainty.

In the 1990s advocates of the Third Way admired the manner in which economic globalisation was driving global growth and development. The challenge now, they thought, was to ensure that nations, as well as communities and individuals, could benefit. A combination of free markets, light touch regulation, dynamic welfare (combining flexicurity, redistribution and 'rights and responsibilities') and social investment in education, early years and skills became the policy package. The accusation that the left simply bought wholesale into 'neo-liberalism' is misplaced. The aspiration was always to use policy for progressive ends.

But the limited tools deemed available proved quite inadequate to bend global capital to the public good. The light regulation thought necessary in the global economy ushered in instability, banking crisis and recession. The near decade long legacy has been stagnating wages, high unemployment in some countries and increasingly insecure labour markets in others, stalled investment and productivity and rapidly widening inequality. The aftermath has been a public austerity that has slashed away at the social protection and public services that were central to the post-war consensus.

The challenge remains to strike the right balance between markets and the public interest. But the lesson of the last half century is that we should not imagine we can find a 'steady-state' in which both governments and the private sector know their remit and responsibilities. Dynamic markets rarely develop in the way we expect. The extraordinary rapid introduction and spread of new technologies makes the future ever harder to predict. Markets find opportunities that neither states nor other market players can spot. The problems created by markets turn out to be unpredictable too. Instead of seeking a predictable and stable settlement, the centre left must envisage a constant effort, continuously fashioned and refashioned, to challenge and hold to account the most powerful economic forces. The measures that could challenge both market failures that emerge as well as the unacceptable concentrations of power and influence that dynamic markets create are not a mystery. Action can be taken against market abuse, tax havens can be wound up and transparency made the norm; regulation can favour business activity that serves a public good over damaging speculation; the state can foster research; public procurement policies can create markets innovative goods; competition policy can favour the new entrant over current market leaders and apply a public interest test to takeovers and foreign ownership; intellectual property rights can favour innovation and enterprise and resist monopoly exploitation; financial reform can create institutions focused on sustainable regional economies; free trades unions and transparent remuneration policy can bring work place justice.

The idea of state and popular institutions continually and actively challenging market power needs to become the new 'common sense' of our society. Just as the right made free-market liberalism the common sense of economics for thirty years, social democrats need to embed the assertion of the common good and the public interest over pure market outcomes as central to our national purpose. This is not an impossible goal. The banking crisis has led to much greater awareness of 
"This is the peer reviewed version of the following article: Denham, J. (2017), A New Progressive Patriotism. The Political Quarterly, 88: 97-105. doi:10.1111/1467-923X.12326, which has been published in final form at http://dx.doi.org/10.1111/1467-923X.12326. This article may be used for non-commercial purposes in accordance with Wiley Terms and Conditions for Self-Archiving." (c) 2017 Wiley-Blackwell

corporate and personal tax avoidance, and widening inequalities of wealth. Popular concern about elements of business behaviour has risen sharply. Yet social democracy is in decline. Public anger at market excess has not translated into political support for action to tackle it. Across Western Europe working class voters are deserting social democratic parties, often for parties that play to a very different tune. Political philosophies once banished to the fringes are re-emerging.

At national level, it is easy - not least in Britain - to point to mistakes made by the left's leaders, but the widespread decline of social democracy demands a more profound explanation.

Social democracy is a collectivist philosophy. It has and will always depend on the support of a large section of society sharing a strong collective sense of identity and a common interest. Popular support for social democracy has always rested on the politics of identity. Social democratic parties were not supported simply or even primarily for their policies or ideologies but because they were seen as expressing the collective interests of the industrial working class. Yet what Marquand called 'labourism' is shrinking in size and political weight. On the left no new collective identity has yet been shaped to fill its place. To understand why, we need to consider the crucial role that political identity relationships play in support for political parties.

\section{Political identity and political relationships}

Although Marquand thought that Labour's identification with the organised industrial working class was politically limiting, he recognised its historic importance: 'Labour rose as far as it did because [the primacy of working class interests] seemed to millions of working class voters to make sense of their experiences.' Solid working class culture was built on a network of relationships - big workplaces, tight communities, family links in and out of work, chapel, church, social club, trade union. In that culture, voting Labour was a way of expressing working class identity. It was both more, and less, than a political relationship; it was a statement of 'who we are', and 'who is on our side'. The experiences that forged that identity also forged its own values; a tough minded collectivism where the community looked after its own but looked askance at those who didn't pull their weight; a community that took pride in defending its interests against threatening change. What is loosely called 'social conservatism' is not an ideological disease but may well be the values of people who knew that if they didn't look after themselves, no one else would.

The work and social institutions that sustained a collectivist, labourist culture have shrunk rapidly over the past 30 years. As that identity loses substance, the umbilical link with voting Labour withers. That's what former Labour voters mean when they say 'Labour doesn't stand for people like me anymore'. Labour and its sister parties have lost touch with socially conservative working class voters concerned about economic marginalisation, security, community, unfairness in the welfare system and the impact of mass migration. But these are not simple policy failures that can be rectified by a better political programme or more persuasive leaders.

Social democracy's political identity relationship with those voters has decayed for reasons beyond policy. Contrary to the belief and hopes of party activists, most voters do not vote for programmes, manifestos or ideologies. They vote for political parties with which they identify. Not so long ago, Labour canvassers were told to ask 'which party do you most closely identify with'. The question recognised that a voters' choice of party was not necessarily the one with the best policies, the best leader, or even best for you personally. It was the party that best expressed who you thought you were.

The changing economy alone would have weakened the relationship with Labour, but rapid migration has had a toxic and understandable impact in vulnerable communities. It seemed to challenge and undermine the last residual sense of who 'we' are - 'the people who live round here'. 
"This is the peer reviewed version of the following article: Denham, J. (2017), A New Progressive Patriotism. The Political Quarterly, 88: 97-105. doi:10.1111/1467-923X.12326, which has been published in final form at http://dx.doi.org/10.1111/1467-923X.12326. This article may be used for non-commercial purposes in accordance with Wiley Terms and Conditions for Self-Archiving." (c) 2017 Wiley-Blackwell

Labour's association with massive and rapid migration was a confirmation that the party no longer stood for them.

Labour's problem is not restricted to its declining industrial working class base. Its identity relationship with other groups of voters is under threat. For example Labour still benefits from a political identity relationship with black and Asian voters established when its anti-racism opposed overt Tory bigotry. But identities formed decades ago are now strained in a more diverse and accepting society. Younger generations have issues and aspirations that are not defined by the migrant experience. Class, religious practice and socially conservative attitudes are eroding the identity relationship and Labour is unclear how to establish a new relationship for the future

Labour is also failing to make inroads into areas of the country and society where it has never been strong. Labour has no base in swathes of southern England. Huge numbers would never dream of voting Labour: even in good years the party has only pepper pot representation. However, there is no significant difference in public attitudes between the south and other English regions. Average incomes may be somewhat higher in some parts of the South, but even in those areas many do not enjoy the wealth around them. It is the lack of any political identity relationship that is Labour's problem. Millions of southern voters live in communities that have never had a strong industrial working class base. Nothing in their own experience of work and community has created that sense of Labour identity that was once so strong in mining districts and some industrial towns. Indeed, Labour is clearly seen to stand for people who are not like them.

This is not a purely English experience. Across Western Europe, once powerful social democratic parties are losing votes to political forces that exploit identity politics effectively: often from the right, sometimes from the far left or as in Scotland, from the centre-left. Only Pasok in Greece has suffered a greater electoral decline than Labour in Scotland, but nowhere has social democracy emerged unscathed including Germany's SPD. . There are particular factors in each country, but there are common threads: working class identity has been disrupted by economic change and the social and economic impact of mass migration; and the modern economy is not generating new class identities.

The exception to these weakening identity relationships is the relative strength of support from a younger, more diverse, liberal section of society that is mirrored by the dominant membership of the Labour Party (and to a considerable extent in other European social democratic parties). Though this part of society is growing, particularly in larger cities and in some university towns, it is by no means large enough to provide a sufficient base for a new radical politics. In the debate that has consumed Labour since 2015, the Corbyn leadership emphasises the need to create a party that reflects its memberships' world view. This underlines the extent to which his support is as much about identity as it is about politics. It allows little space for other world views, let alone the idea that politics involves engaging with people with different ideas and different views.

\section{Today's progressive dilemma}

The changing shape of the economy and employment, divergent educational paths, heterogeneous lifestyles, new technologies, decline in the churches and the social, economic and cultural impact of mass migration have all undermined the sense of 'us' 'we' 'our common good' 'our collective interest' on which social democratic collectivism could thrive. Our individual experiences of work and society are diverging, and far from sustaining common values, they are undermining them. Far from strengthening shared values, institutions like the welfare state have become new sources of division: people look at the entitlements of their neighbours with suspicion. No longer believing that governments can serve a common interest rather than their own, they 
"This is the peer reviewed version of the following article: Denham, J. (2017), A New Progressive Patriotism. The Political Quarterly, 88: 97-105. doi:10.1111/1467-923X.12326, which has been published in final form at http://dx.doi.org/10.1111/1467-923X.12326. This article may be used for non-commercial purposes in accordance with Wiley Terms and Conditions for Self-Archiving."

(c) 2017 Wiley-Blackwell

accept failures like the housing market as beyond policy solutions. The self-organised institutions where people once came together to pray, or study, or socialise, or organise, are weaker. Where they are strong they tend to bring together people who already identify with each other, something that is even more marked in the on line world.

This produces a profound paradox. On the one hand our analysis and experience of modern capitalism suggests that a large majority of people, including the great majority of those engaged in business, share an interest in a sustained effort to restrain the concentration of power and wealth in the hands of a few. On the other contemporary global capitalism is undermining the culture and institutions that sustained a common identity of economic interest in the organized, industrialised, working.

Social democracy needs a new politics of identity that will sustain the majority needed to change the common sense of economic life. This will only happen if a shared interest in holding capital to account is reflected in a shared sense of identity; a sense of identity that can be expressed in support for progressive politic parties and progressive values. This is a nutshell is today's progressive dilemma.

\section{Nation, people and place - the new politics of identity}

The opportunity for a new identity politics is arising from the popular reaction to globalised capitalism. Global capitalism is not producing new class identities it is generating and strengthening other identities. As collective class identities weaken, the new identities of nation, people and place are filling the gap. The human response to the sweep and power of global capitalism has not been a global sense of citizenship. Instead people have turned to more local identities to provide a sense of security in a fast changing and unstable world.

Across Europe and the USA, the most dynamic political forces come from a new identity politics rooted in nation, people and place. In the UK, the parties that have made most progress in the past ten years are UKIP and the SNP. Though their political programmes are very different (as Sanders was different to Trump) they have built a political identity relationship with voters based on 'understanding and speaking for people like us'. Political identity relationships also help explain the relative resilience of Labour in Wales, and the appeal of Syriza in Greece. By contrast the least dynamic forces are those of disappearing identities - the industrial working class and, less remarked but still important, an older conservatism of tradition, services and status that also feels discomforted by globalised market capitalism.

Our nations give us a historic sense of identity, a rooted sense of who we are, and the values we share. In a world that seems to say 'we are all on our own', nation can give a sense of shared purpose and offers traditions of odds overcome and powerful forces defeated. The renewed sense of national identity may well be strongest amongst the parts of society that have done least well socially, economically and politically in the past thirty years. This alone makes the nation a key identity for social democrats wanting to re-connect with former voters. National identity, though, is felt much more widely across the electorate. It is one of the few identities in modern societies capable of providing a unifying rather than a divisive identity.

At the same time, where we live offers a more local identity. These local identities can be a source of pride and even resistance against an overbearing centre in a centralised nation like England. They are where we say we are most at home with our neighbours, and where the practical task of building cohesion from diverse communities may be most advanced. The politics of place, too, 
"This is the peer reviewed version of the following article: Denham, J. (2017), A New Progressive Patriotism. The Political Quarterly, 88: 97-105. doi:10.1111/1467-923X.12326, which has been published in final form at http://dx.doi.org/10.1111/1467-923X.12326. This article may be used for non-commercial purposes in accordance with Wiley Terms and Conditions for Self-Archiving."

(c) 2017 Wiley-Blackwell

unites rather than divides. Labour councils have often found it easier to forge alliances of common interest across communities and business than has the party at national level.

The spontaneous growth of identity politics of nation and place has enormous progressive potential if the social democratic left can understand and engage with it. Quite understandably, progressives shudder at the dangerous rhetoric and actions of the populist right. But the politics of nation, people and place have not been created by the right; they have been a natural human response to a world of insecurity, where major problems appear beyond the power of governments. The right though has been much quicker to exploit this change, and to define the terms of the debate. But, as the SNP, Plaid, Syriza and others have shown, the politics of nation, people and place can also be harnessed by the centre, left and far-left. In the hands of the right, 'the people' can be ethnic and defensive, but 'the people' can also be everyone who shares this place. The dangers are real, but so are the opportunities.

National identity bridges the gulfs emerging across our society; in the places we live often we have our strongest shared identities. In both the majority define 'the people' as all the people who live here, not those of one ethnicity, faith or class. If social democratic politics are to have a future they will need to become progressive patriotic parties of nation, people and place. This cannot be a tactical, electoral appeal to sections of the alienated working class. It has to become a new operating paradigm; a new way of conceiving of these parties as best able to speak for the identities their fellow citizens increasingly share.

\section{Progressive patriotism}

In Britain, the decline of the old Labour class identity is further weakened by the decline of British identity as a single, unifying national identity. Over recent decades, both Scottish and Welsh identities have been asserted more strongly. There is now a growing sense also of English identity and of English political interests. Our argument for a progressive patriotic politics is not restricted to any individual nation. In the British context, the future of the Union may well depend on the development of progressive patriotic politics in each nation, coming together in common interest rathr than the expression of history or sentiment. How Labour might turn that growing English identity into a progressive force is the concern of the rest of this essay.

We consider six major challenges to creating a party of progressive patriotism:

- holding capital to account in the national interest and making this a progressive 'national' cause

- identifying shared national values that express a strong sense of 'who we are' and what we have in common

- building institutions that will sustain common identities and values without reliance or dependence on the state or political activists

- enabling the left to master the cultural politics of national identity building

- fostering such a politics within the realities of today's Labour Party.

- making a progressive patriotic argument for a post Brexit England and post-Brexit Britain

Holding capital to account in the 'national interest' 
"This is the peer reviewed version of the following article: Denham, J. (2017), A New Progressive Patriotism. The Political Quarterly, 88: 97-105. doi:10.1111/1467-923X.12326, which has been published in final form at http://dx.doi.org/10.1111/1467-923X.12326. This article may be used for non-commercial purposes in accordance with Wiley Terms and Conditions for Self-Archiving." (c) 2017 Wiley-Blackwell

It may be no accident that the social fragmentation caused by economic change has been so marked across the whole UK. No state has arguably gone as far in allowing the take-over of domestically owned companies, the spread of private companies into the ownership and management of the public sphere, the acquisition of land and homes by foreign companies, or the penetration of corrupt overseas money into our financial, legal and property markets. In short, no country has gone as far in abandoning the notion of a common good in favour of the outcomes of unrestrained markets. Yet the ever greater penetration of the UK economy by foreign ownership of companies, public spaces, public services, former public utilities and private housing has not delivered the improvements in productivity and investment that liberal market theories promised.

The starting point for progressive patriotic politics is to re-assert a doctrine of the national interest and put the interests of the majority at the heart of economic policy. Progressive patriotic politics would have the confidence to make national interest judgements on issues of foreign ownership and investment. It would be actively engaged with private business in shaping Britain's economy. It would reform the rules on corporate governance; restructure investment and finance, support innovation and shape regulation, procurement and long-term infrastructure in order to create new market opportunities and investment certainty for Britain's most competitive companies. It would demonstrate new confidence in the ability of the public sector to deliver for the public good.

\section{Identifying shared national values for progressive change}

After the EU referendum a crude caricature emerged of an unbridgeable divide between cosmopolitan liberals and the 'left behind' working class. This picture leaves out millions of people probably the majority - and it suggests shared values cannot be found and built upon in our society.

Popular values have indeed diverged, hollowing out the 'centre ground'. Voters disposed to radical change want more radical change. People concerned about insecurity and change are more insecure. People who look first at what a politics offers them are less inclined to believe anyone can deliver. Popular values determine the scope for political change. However, there is much more potential for common ground than much commentary implies, so long as it is understood that the values of the liberal, cosmopolitans cannot t be the centre ground of a national consensus. Three areas of common ground need to be built on.

- First, the NHS remains popular despite its flaws. The view that 'we all pay in and it's there when we need it' reflects a deeply held view about the kind of country we want to be and how we relate one to another.

- Secondly welfare. The present system with narrow means-tested, needs based scope fosters myths of abuse and is out of step with popular ideas of fairness and contribution. Yet 'focus groups' have shown consistently strong support for a welfare system that looks after those most in need, but at the same time takes into account contribution based on time living, earning and paying in within a given community in determining rights and benefits.

- Thirdly migration. There is broad support for sensibly managed immigration so long as it is seen as under control, and the impact measured and mitigated. The politics of nation, people and place requires some limits to the pace of migration and change, but does not demand xenophobic responses. There is a deep depth of tolerance for difference, provided there is no special treatment and everyone 'plays be the rules'. 
"This is the peer reviewed version of the following article: Denham, J. (2017), A New Progressive Patriotism. The Political Quarterly, 88: 97-105. doi:10.1111/1467-923X.12326, which has been published in final form at http://dx.doi.org/10.1111/1467-923X.12326. This article may be used for non-commercial purposes in accordance with Wiley Terms and Conditions for Self-Archiving." (c) 2017 Wiley-Blackwell

There is a toughness and practicality to popular values that modern social democrats can find difficult. The insistence that to benefit fully from society you should be a contributing member of it is demanding and to an extent illiberal. It is, however, a pre-condition for forging the collective identity that a progressive patriotism demands. The role of social democracy is to forge these widely shared assumptions into a set of progressive values that are not the property of the left, but an expression of the values of the nation. As with economic policy, the strategic aim is to embed progressive values within the 'common sense of the nation'.

\section{Building institutions that sustain progressive patriotic values}

In the past progressive values were nurtured in popular institutions autonomous from the state. Today unions are in decline; large workplaces and their social institutions are shrinking; most church congregations are falling; trustee based pension schemes are closed to new members; former mutual savings institutions became drivers of the banking crisis; the English tradition of voluntarism is being undermined by the contract culture; and public universities are now part of a market for higher education.

The picture is not entirely bleak. There is a dynamic 'third sector': charities and volunteering remain storing. But the progressive patriotic left will need to spend as much time fostering new institutions that can develop and sustain their own collective identities as it will working on state delivered policy solutions. We will need new popular institutions, favoring community ownership of energy production and distribution, new mutuals for social care provision, community owned schools and member trustees for the growing assets of NEST.

The politics of place goes with the grain of the need to decentralise and devolve power to local cities and counties. Decentralisation, devolution and empowered local leadership will be the key to improved economic performance, more even regional economic growth and more equal and inclusive growth. The same empowered leadership and stronger local institutions can provide the cultural creativity and leadership that will strengthen local identities.

\section{Mastering the politics of national identity building}

Nations cannot be built on abstract liberal principles. At a high level, the values of democracy, equal treatment, and the rule of law now legally defined as 'British values' are shared by all other democratic nations. It is our particular history - how we came to religious tolerance, how democratic rights were achieved, and the evolution of our approach to law - that makes these national values. Knowing these were achieved through struggles and campaigns - they do not come with the water or the air - makes the nation something that is constantly being built and rebuilt generation by generation.

In our history we find ideas, like the common weal or the common good that constantly reappear in support of popular demand to hold the powerful to account. Knowing our history explains why we are diverse, and have been for much longer than many think. It is also the starting point for building an argument that diversity, with the languages and links they bring, itself makes us well equipped to succeed in a globalised world.

The imperative of nation-building supports the need to bring together communities divided by race faith and recent migration. Building and strengthening local identities is also crucial in creating a genuinely cohesive society out of one that has experienced such rapid demographic change. A progressive patriotic national story must be more than a collection of groups distinguished by race, 
"This is the peer reviewed version of the following article: Denham, J. (2017), A New Progressive Patriotism. The Political Quarterly, 88: 97-105. doi:10.1111/1467-923X.12326, which has been published in final form at http://dx.doi.org/10.1111/1467-923X.12326. This article may be used for non-commercial purposes in accordance with Wiley Terms and Conditions for Self-Archiving."

(c) 2017 Wiley-Blackwell

faith and history trying to live in the same place. It demands a shared national story of how we all came to be here, and what sort of country we want to I build together. And in today's Britain, this means stories of the individual nations as well as what we share together.

\section{Making Labour a progressive patriotic party}

David Marquand wanted Labour to reach beyond its labourist base. Today the challenge is to reach beyond the comfort zone of its increasingly graduate, middle class, liberal and public sector membership and the places where this gains electoral support. The recent leadership contest disguised the extent to which both dominant wings of Labour are uncomfortable with much of the nation they want to represent.

For Labour, progressive politics of nation, people and place provides the opportunity to win back lost voters. It opens up the possibility of establishing new relationships with voters who have never shared the labourist tradition and whose personal experiences have been different, like those in southern England.

Across most of western Europe, most social democrats seem to prefer staying firmly in their comfort zones while the politics of the populist right and left gain support. The reinvention of the Labour in the UK is as challenging as anywhere. In the complexities of the UK, Labour will need to reflect both national and British identities. Scottish Labour will have to find a compelling national story of Scotland within the Union is essential if it is to recover. Welsh Labour has already sought to combine progressive Labour values with a distinct national story. Labour's debate about England is only just starting, though the essential calls for an 'English Labour Party' within UK Labour are growing.

\section{Making a progressive patriotic argument for a post Brexit Britain}

Labour's approach to Brexit will provide the first chance to express a progressive patriotism. Most Labour activists and voters rightly supported Remain but the Leave vote has created a new politics and expectations, including amongst the Remain voters who harboured deep reservations about the current EU offer. Though it would have been better to argue for reform from within, the left is in danger of arguing for a cut price, second rate membership, accepting free movement in turn for single market access but little influence on decision-making. Such an outcome would further fracture our society and politics, weaken Labour's appeal to its erstwhile supporters and create no new support.

The progressive patriotic option is to accept the Brexit decision and set out a radical approach to our new status. This should be in stark contrast to the global, liberalising, anglosphere approach of the leading Brexiteers. In the longer term Britain's future might well be within a reformed EU, but for now the priority should be to set out what a progressive patriotism needs from Brexit in four key areas: immigration, national economic policy, international trade deals and international leadership.

- Labour should argue for an end to free movement in its current form, enabling limits to be placed on EU as well as global migration. The party should also advocate effective planning for population change, setting out how the social, cultural, economic and public service impact of change (including that from existing new migrants) will be handled.

- A progressive national economic policy would make full use of the freedom from singlemarket rules - particularly around state aid and procurement - that would allow a new national focus to our economy. 
"This is the peer reviewed version of the following article: Denham, J. (2017), A New Progressive Patriotism. The Political Quarterly, 88: 97-105. doi:10.1111/1467-923X.12326, which has been published in final form at http://dx.doi.org/10.1111/1467-923X.12326. This article may be used for non-commercial purposes in accordance with Wiley Terms and Conditions for Self-Archiving." (c) 2017 Wiley-Blackwell

- Labour should campaign for the introduction of new national interest competition policies.

- In trade policy, the party must resist the desire of the global liberals to open our economy and public services to damaging unfair competition.

- Labour should make it clear that being outside the EU does not mean that we have lost confidence in Britain's ability to offer global leadership on climate change, security, financial reform and other issues.

Labour should be explicit about its desire to heal the divisions, building a nation around shared values. Some will object that this approach takes no account of the realities of EU negotiations, but Labour is a long way from having to lead in those talks. The party needs a sharp break from a politics that is defined by elite conversations. A nation that is confident and united about what it wants is more likely to achieve a good outcome than one that is fearful and divided. 